\title{
Expanding Infrastructure And Environmental Protection - Indissoluble Contradiction Or Reasonable Symbiosis?
}

\author{
Academic Director Dr. Phil. Assessor jur. Franz-Rudolf Herber \\ Frederic-Alexander University Erlangen-Nuremberg
}

doi: 10.19044/esj.2016.v12n1p19 URL:http://dx.doi.org/10.19044/esj.2016.v12n1p19

\begin{abstract}
The expanding of infrastructure (roads/energy) is necessary as well in the developed countries as well as in the emerging countries: But the approach is different: In the developed countries the preservation of the given infrastructure is more important than new infrastructure. In the emerging countries necessary infrastructure is lacking and should be erected. Nevertheless, the management of such measures have to take the protection of environment into account. Those, who do not have any respect for nature, are behaving wrong. The belief, that such behaviour does not have any negative effects, is wrong. Nature does not endure any maltreatment and cannot endlessly recycle itself. But nature is a power that might be underestimated: If nature takes revenge on mankind, the consequences are drought, tornados and the drop of the sea level. Of course, if ones does have a religion, the answer has to be that the revenge of God will be severe, the Bible does call it apocalypsis or the end the world.
\end{abstract}

Keywords: Climate change, economy, education, expanding infrastructure, environmental protection, road network, road safety, by-pass, nuclear energy, wind energy, solar energy, Bible, Henry Thoreau

\section{Introduction: Is there an apocalypsis near?}

The following text shows that an expanding infrastructure and environmental protection are not an indissoluble contradiction, but a reasonable symbiosis ${ }^{2}$. Here should be started with a thought experience; imagine the following horrible scenarios ${ }^{3}$ :

\footnotetext{
2 This paper was the basic for my key-note speech at the $4^{\text {th }}$ International Scientific Forum, ISF 2015 on $2-4$ September 2015 at the University of Oxford; the speech did start with the following words of thanking: "First of all, I have to say thank you to the organizers of this congress that you give me the opportunity of making a key-note speech to the audience here in one of the oldest universities of the world. The University of Oxford is today still
} 
- $\quad$ The rainforest in Brazil ${ }^{4}$ is cut down ${ }^{5}$.

- $\quad$ The river Nile ${ }^{6}$ is silted ${ }^{7}$.

- $\quad$ The metropoles of London, Paris and Beijing do suffer permanently from $\operatorname{smog}^{8}$.

Thank God, these horrible scenarios are until now not real, but these scenarios may be real in a few decades, may be in a few years. Yes, it is high time that the governments have to do something against the climate catastrophe. It does not help, that some people repeatedly want to point out that in human history there had been several changes of climate and that these non-cyclical changes are nothing particular, so that there is no real cause for alarm. Who argues in these old patterns, is not aware of the conditions on this planet that occurred in the 20th century and that do occur in the 21st century; these developments do differ fundamentally from the conditions in the old world; the following is obvious:

(1) The car has conquered the world down to almost its last corners. There is a high degree of mobility by automobiles; this affects the environment by CO2-emissions ${ }^{9}$ in unimaginable dimensions. Many countries do invest a lot of their budget for new road infrastructure - much more money than for education.

(2) Modern industry has led to a huge increase in production: Discounter stores ${ }^{10}$ provide us with goods of all kinds. As all of us do know, it is not always fair trade ${ }^{11}$, if products are imported from Asia and Africa to Europe.

one of the first addresses of science in the whole world. Today, for me a childhood dream is fulfilled. Furthermore, I have to say thank you to Mr. Jovan Shopovski from Macedonia, who is the president of the European Scientific Institute. His busy cleverness and his bright intelligence are the reasons, why the European Scientific Institute and European Scientific Journal are success stories. It seems to me that Macedonia - it is the land of Alexander the Great - should become a member state of the European Union as soon as possible”.

${ }^{3}$ Cfr. Parag Khanna: How is the world ruled, Berlin, 2012, p. 252.

${ }^{4}$ Richard T. Corlett \& Richard B. Primack: Tropical Rainforest Conservation: A Global Perspective, in: Walter Carson and Stefan Schnitzer (ed.): Tropical Forest Community Ecology. 2008, Chapter 26.

${ }^{5}$ Still there now roundabout 3 trillion trees; cfr. Berlin Newspaper, N0. 205, 3rd of September 2015, p. 12.

${ }^{6}$ Cfr. http://www.infoplease.com/encyclopedia/world/nile-irrigation-along-nile.html .

${ }^{7}$ There is no life possible without water. The German Spiegel-Magazine published in 2015 an impressing report on the subject "World without Water" (N0. 83, $8^{\text {th }}$ of August 2015, pp. $8-16)$.

${ }^{8}$ The word smog is an artefact of the words $>$ smoke $<$ and $>$ fog $<$.

${ }^{9} \mathrm{Cfr}$. http://www.epa.gov/climatechange/ghgemissions/gases/co2.html .

${ }^{10}$ The German discounter ALDI was founded by two brothers - Theo Albrecht (1922-2010) und Karl Albrecht (1920-2014- that started with a very small retail business.

${ }^{11}$ Amrita Narlikar, Dan Kim: Unfair Trade. The Fair-Trade Movement Does More Harm Than Good, in: Foreign Affairs foreignaffairs.com. 4. April 2013, 
(3) The increase in world population ${ }^{12}$ is a huge challenge for energy demand. The peaceful use of nuclear energy seemed to be a very friendly way as far as environment is concerned. The nuclear disaster at Chernobyl ${ }^{13}$ in 1986 and at Fukushima ${ }^{14}$ in 2011 were the negative highlights. It has become clear and transparent that the peaceful use of nuclear energy has no future.

(4) The space exploration ${ }^{15}$ has not produced the results that are desired: Until now no other planet has been found on which mankind could survive; until now no place has been found from which water and fresh air can be transported easily and at reasonable prices to the earth.

The Earth is still divided in developed countries and emerging countries: Still the following principle is ruling our life: >Economic progress is not feasible without good infrastructure<

When we return to our planet, then we have to complain a division of our planet into two parts (at least two parts):

- On the one hand there are the very wealthy nations, we call these the developed countries ${ }^{16}$.

- On the other hand there are the rather poor countries, we call these emerging countries ${ }^{17}$.

There is no doubt on the following thesis: Economic progress is not feasible without good infrastructure. But what is meant in terms of good infrastructure? This depends on the perspective:

- The developed countries do have a (transport) infrastructure that is very elaborate, but causes various environmental problems. In developed countries there should rule this so very reasonable principle, but it is not yet obeyed:

12 For the development until the year 2100 cfr. http://www.weltbevoelkerung.de/publikationendownloads/infografiken/slide/bevoelkerungsprojektionen-bis-2100.html .

${ }^{13}$ Shoigu/Bolshov (ed.): Twenty years of the Chernobyl accident. Results and Problems in Eliminating Its Consequences in Russia 1986-2006. UNSCEAR, 2008 Report. Sources and effects of ionizing radiation. Band 2. Annex D - Health effects due to radiation from the Chernobyl accident. New York, 2011.

${ }^{14}$ The Tohoku-Taiheiyou-Oki Earthquake and Subsequent Tsunami on March 11, 2011 and Consequences for Nuclear Power Plants in Northeast Honshu, edited by Ludger Mohrbach und Thomas Linnemann.

${ }^{15}$ Maria D. Lane: Geographies of Mars. Seeing and Knowing the Red Planet, Chicago, 2010.

16 Cfr. the publication of World Economic Outlook Database http://www.imf.org/external/pubs/ft/weo/2012/01/weodata/index.aspx.

17 Cfr. the publication of Investment Issues in Emerging Markets http://www.cfapubs.org/toc/rflr/2011/6/1 
"The preservation of the existing (transport) infrastructure has to take precedence over the construction of new (transport) infrastructure".

- In emerging countries necessary infrastructure is not everywhere available. Here we shall hear a voice from Africa; this voice is probably not an isolated case from this large continent: Bafode Diouf is now 31 years old and was born in Senegal; to the following question of the German Magazine $>$ Frankfurter Allgemeine Sonntagszeitung $<{ }^{18}$ in summertime 2015

"What did you most desire as a child?"

there was given the following answer: “(...) A road that shall connect our village to the country". "We could only be reached with cows and carts; water was brought from a fountain ...".

If there were a world government ${ }^{19}$, there would be fundamental universal rights: One of these universal rights would certainly be the right of mobility. Judging by the division of the world into developed countries and emerging economies it is possible to interpret this universal right differently:

- In developed countries it is less about the "if" of transport infrastructure, but more about the "how" of infrastructure: The questions are:

"Will there be soon a faster connection to my town respectively to my village? Where are fast freeways on which I can speed up my car to the limit (200 km - unfortunately - even more)?”

- In the emerging countries it is less about the "how" of transport infrastructure, but more about the "if" of infrastructure: The question is: "Is there a road to my village or not?"

In industrialized countries - particularly in Europe - there is the statistical trend that the number of private cars is growing, although the number of inhabitants goes down and the families do become smaller and smaller; this trend is given in Germany ${ }^{20}$ for the last decades.

\section{What is necessary for a good transport infrastructure?}

For a good transport infrastructure there are several necessities; the public roads should be divided into the following categories ${ }^{21}$ :

- Freeways (motorways),

- Highways (expressways),

\footnotetext{
${ }^{18}$ Edition of the $9^{\text {th }}$ of August 2015, Nr. 32.

${ }^{19}$ The United Nations are not a world government, because one veto power can block whatsoever reasonable proposition.

${ }^{20} \mathrm{Cfr}$. for the situation in Germany the following internet source www.destatis.de/DE/ZahlenFakten/Wirtschaftsbereiche/TransportVerkehr/UnternehmenInfr astrukturFahrzeugbestand/Tabellen/Fahrzeugbestand.html.

${ }^{21}$ Cfr. Franz-Rudolf Herber: Egyptian Road Act Proposal, in: Without Editor: The EU twinning expertise for Enhancing Road Safety on Egypt, 2nd edition, Cairo 2012 disc, under Annex, No. 53, p. $1-86$.
} 
- Main roads,

- Regional roads, and

- Local roads.

This division $^{22}$ or a similar division is reasonable, because there must be served different types of traffic ${ }^{23}$ : Extreme high-speed traffic is to be mastered by freeways (i.e. $>120 \mathrm{~km} / \mathrm{h}$ ), high-speed traffic (i.e. $80-120$ $\mathrm{km} / \mathrm{h}$ ) is to be mastered by highways; average-speed traffic (i.e. $80 \mathrm{~km} / \mathrm{h}$ ) is to be mastered by main roads and regional roads; the traffic that is less than $50 \mathrm{~km} / \mathrm{h}$ is to be mastered by local roads.

\section{a) Freeway (motorway) network}

For a good transport infrastructure there is a good network of freeways necessary; it does serves several purposes, e.g:

- Goods of all kinds can be transported quickly and without loss of time from point $>\mathrm{a}<$ to point $>\mathrm{b}<24$.

- Saleswomen, salesmen and all other individuals, who do want quickly move from point $>a<$ to point $>b<$, can rely on the freeways, only in a very few and exceptional cases there is a direct flight ${ }^{25}$ that is faster.

How can freeways be defined by law; here is a proposal:

"Freeways are intended for use by high-speed vehicular traffic only and designed search that they have no at-grade crossings and are equipped with special junctions for access and exit. Access to the freeways shall be provided only at pre-determined locations from service roads through properly designed entry ramps and exit ramps. Freeways should have separate carriageways for the two directions of traffic. Freeways have to be designed without any U-turns. There is no direct access for frontage residents allowed. Slow traffic (particularly pedestrians, and guided bicylces cattle) is not allowed to use freeways ".

What is typical for freeways?

- Freeways are dedicated exclusively for high-speed traffic ${ }^{26}$.

- Typical of freeways is the intersection-free traffic flow ${ }^{27}$, it shall ensure that the risk of accidents is reduced.

\footnotetext{
${ }^{22}$ Cfr. § 1 German Highways Act.

${ }^{23}$ Franz-Rudolf Herber, in: Kurt Kodal, Handbook on road law in the Federal Republic of Germany. 7th edition. Munich, 2010, Chapter 10.

${ }^{24}$ For the industry the transport just in time is of great importance.

25 To the environmental pollution by aeroplanes http://wiki.bildungsserver.de/klimawandel/index.php/Auswirkungen_des_Luftverkehrs .

${ }^{26}$ For details Franz-Rudolf Herber/Sebastian Heidorn: Speed limit on motorways, in: Bavarian Administrative Law Journal 2009, 129 - 137.

${ }^{27}$ Cfr. § 1 paragraph 3 German Highways Act.
} 
- Typical of freeways is the traffic flow function. This does not mean that traffic has to flow very fast, but this does mean that traffic flows (unhindered) continuously and quite fast.

- The text of every Public Roads Law shall make absolutely clear $^{28}$ that private persons or private juridical persons cannot attain privileged access to freeways because their land-property ${ }^{29}$ is close to motorways ${ }^{30}$.

- Typical of freeways is that these roads are attracting the regional transport: This means that the regional transport calculates the time savings that can be achieved on the freeways ${ }^{31}$.

- There shall be emergency lanes along freeways, which can be used by the maintenance service and by damaged cars.

\section{b) To the further road network}

Of course, it is not sufficient to have a network of freeways. It is very important that highways and main roads do bring the traffic to the freeways; therefore private access to highways and to main roads has to be limited, so that the traffic can flow as unhindered as possible:

"(1) Highways and main roads have no direct access for frontage residents outside of built-up areas. Access is only allowed by three way junctions. Slow traffic (particularly pedestrians, and guided bicylces cattle) can be allowed to use mainroads by virtue of particular traffic signs.

(2) For all other road categories new direct accesses to the roads are only allowed within built-up areas.

(3) Particular regulations do refer to the constructing of Public Roads are ruled by the Ministry of Transport by virtue of a decree".

\section{c) Bypasses}

Of course, it is a big problem for long-distance traffic to go through villages and towns; there the local road network has to be integrated in the network of higher ranking roads, but not the total local road network, only that part of the local road network that is necessary to give guidance to the

\footnotetext{
${ }^{28}$ Unfortunately facilities for rest areas are not mentioned in the Serbian law. Facilities for rest areas are of high importance, which in a legal sense are part of the motorways network. The areas are furthermore very important for the drivers of goods traffic, who have to observe the regulations for resting-periods. This rest-areas are only dedicated for the needs of the rapid traffic. The inhabitants of towns and villages nearby do not have direct access to the rest-areas, so that the aspect of road safety is taken into account.

${ }^{29}$ Franz-Rudolf Herber: On the importance of expropriation in the Roman Empire and in modern Europe, in: European Scientific Journal 2015, Volume 11, No. 1, p 1. - 22.

${ }^{30}$ Cfr. § 1 paragraph 3 German Highways Act.

${ }^{31}$ Franz-Rudolf Herber, in: Kurt Kodal, Handbook on road law in the Federal Republic of Germany. 7th edition. Munich, 2010, Chapter 10.
} 
high speed traffic; the following text should be implemented in the Roads Act of every country ${ }^{32}$ :

"Within built-up areas the coherent transport network shall include those roads of the local network that are indeed necessary to accommodate long-distance traffic".

There is no doubt that the construction of bypasses is the very best solution:

- Thus the high speed traffic is taken out from villages and towns.

- The residents in the villages and town are relieved from traffic hazards and traffic noise ${ }^{33}$.

I give you an example from my working experience for the European Union $^{34}$ in Egypt ${ }^{35}$ : Between the giga-metropolis of Cairo and Alexandria ${ }^{36}$ there is quite a good freeway connection that (largely) goes through the desert. Between the two cities there is also a road link that runs through the fertile fields in the area of the river Nile and has pre-eminent importance in particular for freight transport. The long-distance traffic has to work its way through a number of towns and villages in a very dangerous manner; the rate of traffic accidents and of casualties is extremely high. What is the right solution here? The long-distance traffic has in any case to be carried around the towns and the villages; thus high speed-traffic and slow-speed traffic should be separated.

\section{Road safety measures as measures for environmental protection}

The next point is the following: Road safety ${ }^{37}$ measures are also measures for environmental protection. Free democracies should not monitor mobility of individual people or of groups of people like police states. But this does not rule out to take measures for

- protecting the road infrastructure itself,

- protecting the road users, and

\footnotetext{
${ }^{32}$ Cfr. Franz-Rudolf Herber: Egyptian Road Act Proposal, in: Without Editor: The EU twinning expertise for Enhancing Road Safety on Egypt, 2nd edition, Cairo 2012 disc, under Annex, No. 53, p. $1-86$.

${ }^{33}$ In this publication the bypassing construction was started without approval from the environmental body http://www.nation.co.ke/News/-/1056/526376/-/u1wl58/-/index.html .

34 For the staff from Germany the GIZ is responsible; cfr. http://www.giz.de/en/html/about_giz.html.

${ }^{35}$ Cfr. Franz-Rudolf Herber: Egyptian Road Act Proposal, in: Without Editor: The EU twinning expertise for Enhancing Road Safety on Egypt, 2nd edition, Cairo 2012 disc, under Annex, No. 53, p. 1 - 86.

${ }^{36}$ The antique Alexandria was famous for its library.

${ }^{37}$ The term "road safety" is an Anglicism, that is incorporated in the German language and many other languages of the world; any translation of "road safety" may not have the mythical effect that emanates from the English term.
} 
- protecting the environment.

\section{a) General speed limit for freeways}

Here it has to be mentioned that in all the Member States of the European Union there is a general speed limit for freeways. But in the Federal Republic of Germany there is still no general speed limit for freeways; this should be changed very soon ${ }^{38}$.

\section{b) Punctual speed limit for dangerous parts of freeway and other roads}

Punctual speed limits ${ }^{39}$ do serve the three purposes mentioned above:

- In bridges (particularly on freeways) the speed should be limited by traffic signs.

- For dangerous curves (particularly on freeways) the speed should be limited by traffic signs.

- For road sections, that are exposed to ice (particularly on freeways), the speed should be limited by traffic signs.

- For road sections, that are exposed to sand dunes (particularly in deserts), the speed should be limited by traffic signs.

- For road sections, which are congestion-related (particularly on freeways), the speed should be limited by traffic signs appropriate to the situation; electronic traffic control systems ${ }^{40}$ are very helpful.

\section{c) To pedestrian areas in cities}

Do we have to go by car into our cities? Why do we not go by public transport, e.g. by bus? In Germany it seems unfortunately clear that very young people and very old ${ }^{41}$ people prefer going by their own car downtown and the best thing for these people is to park the car in front of the town hall. But this is not a reasonable solution: This procedure is not only very selfish, it is also uneconomical and not very ecological. Pedestrian areas in the industrialized countries do exist at least in two variants:

- It is only allowed pedestrian traffic, even cycling is not permitted in order to protect pedestrians in terms of road safety ${ }^{42}$.

\footnotetext{
38 Franz-Rudolf Herber/Sebastian Heidorn: Speed limit on freeways, in: Bavarian Administrative Law Journal 2009, 129 - 137.

${ }^{39}$ In Germany the legal basis is $§ 45$ German Road Traffic Regulations.

40 For details cfr. http://www.bast.de/DE/FB-V/Fachthemen/v5verkehrsbeeinflussungsanlagen/verkehrsbeeinflussungsanlagen.html .

${ }^{41}$ Very old people (i.e. $>80$ years) are still allowed to drive car.

${ }^{42} \S 45$ paragraph 1b N0. 4 German Road Traffic Regulations.
} 
- There is allowed pedestrian traffic, whereas cycling is allowed only at certain times, e.g. in the early morning and in the evening (after the socalled rush-hours).

In each of the these two variants it is understood that delivery traffic is allowed at specific times, particularly in the early morning.

\section{d) For limited traffic zones in cities}

According to German traffic law ${ }^{43}$ limited traffic zones are established only downtown. No particular kind of traffic is excluded from this downtown area, but there is for all vehicles an extreme speed limit and this at maximum $20 \mathrm{~km} / \mathrm{h}$, in some cases it is only $10 \mathrm{~km} / \mathrm{h}^{44}$.

\section{e) Traffic management by tolls}

There is the saying "What costs nothing is worth nothing" 45 . The problem is that people can use the roads without paying an immediate "quid pro quo" ${ }^{46}$. In large metropolitan areas such as Cairo or Paris it will be inevitable to introduce tolls, if it shall be allowed that drivers may enter the cardiac area of the metropolis.

\section{f) What about at least one car-free Sunday per year?}

But why do not we have at least one Sunday per year on which cardriving is forbidden, whereas important goods should be transported and emergency services should be allowed? On 25th of November, 2nd, 9th and 16th of December 1973 car-driving was not allowed in West-Germany with the exception of the aforesaid services ${ }^{47}$; the aim was to save fuel in regard of the so-called first oil crisis ${ }^{48}$. The first oil crisis ${ }^{49}$, which is also called oil embargo, had taken place in the autumn of 1973, when the OPEC had throttled the flow rates; this had resulted in an increase in the oil price of three US dollars per barrel and then up to five US dollars per barrel. At that

\footnotetext{
${ }^{43}$ The legal basis is § 45 paragraph $1 \mathrm{~d}$ German Road Traffic Regulations.

${ }^{44}$ It is no doubt that there are good reasons to limit the speed at $10 \mathrm{~km} / \mathrm{h}$. Markus Esch und Manuela Martin - close friends of the author - were both killed as children in traffic accidents in a small village near the river Moselle that had at that time not more than 1000 inhabitants (Besch).

${ }^{45}$ This saying is traced back to Albert Einstein; http://www.aphorismen.de/zitat/131660 .

${ }^{46}$ It is no question that several taxes have to be paid but the immediate context to road using is no longer in the consciousness.

${ }^{47} \S 1$ of the Regulation on driving restrictions and speed limits for motor vehicles of 19 November 1973, Federal Law Gazette I, 1676.

${ }^{49}$ Cfr. http://poq.oxfordjournals.org/content/43/3/285.short.
} 
time Algeria, Iran, Iraq, Kuwait, Libya, Saudi Arabia and the United Arab Emirates had taken part in the action ${ }^{50}$. This car-free Sundays ${ }^{51}$ had at least three other positive effects:

- The emission of CO2 was reduced.

- Many people did experience anew that walking by foot or going by bicycle may be something very interesting.

- Many families did experience anew the group-feeling in families.

We should be happy that the capital of France - Paris - will enjoy a car-free day on $27^{\text {th }}$ of September 2015 from 11.00 to 18.00 o'clock $^{52}$.

\section{g) On the responsibility of automobile industry}

In the so called car-producing countries the interests of the automobile industry are taken into particular consideration. The fearargument is used that production could be shifted abroad. Nevertheless: These companies are run by smart people and are likely to be won by good arguments $^{53}$. It is foreseeable that the oil reserves ${ }^{54}$ are coming to an end and therefore actually everything has be done to promote the establishing of electric cars; the German electric mobility law ${ }^{55}$ is a only a small beginning ${ }^{56}$, but nothing more.

It is very interesting and positive that Article 4 of the Serbian Law on Road Traffic Safety ${ }^{57}$ refers to the responsibility of the Automobile Industry:

“(1) Every legal entity or entrepreneur which operates in the areas of production, maintenance, trading, repairing or modification of vehicles, related devices, spare parts and vehicle equipment, shall

\footnotetext{
${ }^{50}$ The result had been that the Federal Republic had to spend in 1974 for its oil imports approximately 17 trillion DM more than the year before.

${ }^{51}$ It is encouraging that certain Bavarian towns have a car-free Sunday cfr. e.g. http://www.google.de/url?sa=t\&rct=j\&q=\&esrc=s\&source=web\&cd=1\&ved=0CCEQFjAAa hUKEwiwra_1c7HAhUHnXIKHSfQDmM\&url=http\%3A\%2F\%2Fwww.volkach.de\%2Fd atei.php\%3Fsrc\%3Ddownload\%2Ffwl_autofreier_sonntag-26-

01.pdf\&ei=YNjhVbD9M4e6ygOnoLuYBg\&usg=AFQjCNEeuItpYp20kVYBG1eK2RTp6G mqIw

${ }^{52}$ Cfr. http://de.rendezvousenfrance.com/de/aktuell/autofreier-sonntag-paris .

${ }^{53}$ On new scientific work in England cfr. German Time Magazine, N0. 36, $3^{\text {rd }}$ of September 2015, p. 29.

54

Cfr.

http://www.bgr.bund.de/DE/Themen/Energie/Produkte/energiestudie2014_Zusammenfassun g.html;jsessionid=CBD18EDF3E98A7D3A04DE9CB83E32CF3.1_cid321?nn=1542234 .

${ }^{55} \mathrm{Cfr}$.

http://www.gesetze-im-internet.de/bundesrecht/emog/gesamt.pdf.

${ }^{56}$ Berlin is testing 204 electro-busses in 2015; cfr. Berlin Newspaper, N0. 203, $1^{\text {st }}$ of September 2015, p. 16.

${ }^{57}$ http://en.abs.gov.rs/download/1025
} 
conduct such business in accordance with regulation and the rules of trade so that the vehicles can safely participate in traffic.

(2) A company, any other legal entity or an entrepreneur which conducts design, construction, maintenance or management of roads shall do so in a manner which enables safe traffic conduct.

(3) Legal entities and entrepreneurs which are referred to in the Paragraph 1 of this Article may conduct aforementioned activities provided they are granted a license by the ministry in charge of trade and services".

\section{h) Road safety in emerging countries}

Road safety is a global issue; in all states of the world efforts there are undertaken in order to ensure a high level of safety for road users ${ }^{58}$. It is not surprising that global organizations are committed to road safety; this applies particularly to the World Health Organization (WHO) ${ }^{59}$ as a body of the United Nations (UN) ${ }^{60}$ and the Organization of the Organization for European Economic Cooperation (OECD). The WHO presented in its $>$ Global Status Report on Road Safety $2013<{ }^{61}$ important results referring to road safety in 182 countries ${ }^{62}$. While there are no uniform ${ }^{63}$ standards for road safety but who would seriously argue that in central European countries such as Germany ${ }^{64}$ in the core there shall be other conditions for road safety as in Eastern European countries such as Poland ${ }^{65}$ or in South East European countries such as Bulgaria ${ }^{66}$ and Serbia? Other countries could be named here.

\footnotetext{
${ }^{58}$ For Europe Cfr. Directive 2008/96/EC of the European Parliament and of the Council of 19 November 2008 on road infrastructure safety management. But European directives need to be implemented by the member states; the member states have some discretion for the implementation.

${ }^{59}$ Cfr. http://www.who.int/en/ .

${ }^{60}$ Cfr. http://www.un.org/ .

${ }^{61}$ Cfr. Under

http://www.who.int/violence_injury_prevention/road_safety_status/2013/en/

62 The WHO did grant Serbia in the year 2013 the sum of US \$ 100 million.

63 Cfr. Directive 2008/96/EC of the European Parliament and of the Council of 19 November 2008 on road infrastructure safety management.

${ }^{64}$ Franz-Rudolf Herber: German Road Law in its constitutional anchoring, in: Konrad Bauer/Franz-Rudolf Herber (ed.), Law and technology, Vol. II, Bonn, 2011, p. 15 - 47.

65 Piotr Swiatecki: Polish Road Law in its constitutional anchoring, in: Konrad Bauer/Franz-Rudolf Herber (ed.), Law and technology, Vol. II, Bonn, 2011, p. 71 - 98.

${ }^{66}$ Franz-Rudolf Herber/Diana Boteva: Bulgarian Road Law in its constitutional anchoring, in: Konrad Bauer/Franz-Rudolf Herber (ed.), Law and technology, Vol. II, Bonn, 2011, p. 341-355.
} 


\section{Energy}

No one can deny that a successful economy needs energy at reasonable prices; this energy should be produced under conditions that give an utmost of protection for environment.

\section{a) To nuclear Energy}

From a technical point of view nuclear energy is an ingenious invention. Under normal circumstances it has no traceable negative effects on the environment. But it has to be seen that the above-mentioned disasters of Chernobyl and Fukushima have unfortunately demonstrated that nuclear energy cannot be controlled: This shows the hybris of mankind: How can mankind rely on an energy that in the end cannot be controlled. The German philosopher Immanuel Kant $\left(1724\right.$ - 1804) ${ }^{67}$ - who was one of the scholar stars of the Enlightenment - believed that the principle of reason is governing the lives of women and men ${ }^{68}$. The establishment of nuclear energy, whereas its risks are known, is a very good example for the sad truth that the great philosopher Kant was wrong; his conception of mankind and human behaviour is too positive.

\section{b) Final depositories for nuclear waste}

Meanwhile the consequences of the peaceful use of nuclear energy in Germany are fully clear. The federal government recognized immediately after the Fukushima disaster, that the classic planning process - the so-called planning approval procedure - is not be a sufficient scenario for the determination of a final repository for nuclear waste ${ }^{69}$. The new solution shall be determined under the comprehensive participation of the population and in the end the legislature ${ }^{70}$ has to decide (Bundestag/Bundesrat ${ }^{71}$ ). This has also the aim that the judicial control is shortened to only one juridical instance:

- Concerned citizens may lodge a constitutional complaint to the Federal Constitutional Court ${ }^{72}$.

- The affected Bundesland - for example Bavaria - may lodge an abstract judicial review by the Federal Constitutional Court ${ }^{73}$.

\footnotetext{
${ }^{67}$ Graham Nicol Forst: Kant's "Copernican revolution" in philosophy and the romantic "revolution" in English literature, 1970.

${ }^{68}$ Kritik der reinen Vernunft, 1. Auflage, 1781.

69 Franz-Rudolf Herber: Zur Endlagerung radioaktiver Abfälle und zum Standortauswahlgesetz, in: BayVBl. 2014, 353 - 362.

${ }^{70} \mathrm{Cfr}$. http://www.gesetze-im-internet.de/standag/BJNR255310013.html .

${ }^{71}$ The Federal Republic of Germany is structured into countries ("Bundesländer") and these do take part in the legislation of the federal republic.

${ }^{72}$ Cfr. Article 93 paragraph 1 number 2 of the German Constitution.

${ }^{73} \mathrm{Cfr}$. Article 93 paragraph 1, number 4 a of the German Constitution.
} 
Even if the relevant law provides a maximum participation of citizens, this does not mean that the acceptance of citizens does increase. The problem is a topographical one: Where shall there be found enough places for a serious selection process in such a relatively small country as Germany? The technical requirements for a final repository are very high: The starting point is the so-called decay time of plutonium and similar substances, which surpasses all human imagination ${ }^{74}$.

What dare we hope: It would be genial, if a new Albert Einstein ${ }^{75}$ occured and showed mankind, how nuclear waste were to be disposed quickly and safely. What do we have to fear: Those companies that have earned very much money with atomic energy for decades, make little efforts to participate in the costs of the final disposal ${ }^{76}$. The nuclear industry expects that the political decision-makers shall burden these costs on the shoulders of the taxpayers; this is hardly a fair result.

\section{c) To alternative energies}

What are really alternative energies? Sun and wind seem tobe such energies.

\section{aa) Sun}

A few years ago the former French President ${ }^{77}$ did make the very good proposal that the European Union should cooperate with those African countries that dispose of desert areas ${ }^{78}$ : It would be a technically very attractive scenario, that solar panels in North African desert areas should be installed and thus the solar radiation is collected. The so produced energy would be directed to Europe. Africa would have the following advantages:

- Africa would become a serious technology partner.

- In Africa new jobs would be established.

- In Africa there would be provided a new technology that could be used for particular African interests. Solar energy seems - as long as this universe exists - to be available in infinite quantities. Why are the consequences from this knowledge not drawn? Certainly a sun-roof on a house is not very aesthetic, but what argument can be given against a law that enacts the obligatory sun-roof? For good reasons some exceptions could be allowed: E.g. historic houses should

\footnotetext{
${ }^{74}$ Cfr. http://de.atomkraftwerkeplag.wikia.com/wiki/Radioaktive_Substanzen .

${ }^{75}$ To him Paul Arthur Schilpp (ed.): Albert Einstein: Philosopher-Scientist. Library of Living Philosophers, Cambridge University Press, Volume VII, London, 1949.

${ }^{76}$ Cfr. German Time Magazine, N0 36, $3^{\text {rd }}$ of September 2015, p. 19.

${ }^{77}$ Nicolas Sarkozy was the President of the Republic of France from 2007 until 2012.

78 Cfr. http://www.spiegel.de/wissenschaft/mensch/parabolspiegel-in-der-wueste-wieeuropa-von-kohle-und-gas-loskommt-a-549677-2.html .
} 
be excluded from the sun-roof-programs; historic medieval towns shall remain untouched.

\section{bb) Wind}

Wind power is available in infinite quantities as long as this universe exists. Why should we not use wind-power? But here the parliaments of our democracies have to resume their responsibility and must guide the planning process of wind turbines ${ }^{79}$. It is the wrong way that this planning process is put into the responsibility of communities: The negative results can be easily foreseen: Wind turbines are established at the municipal boundaries to neighboring communities. This is no solution, the establishment of national wind power programs should be promoted. Here ends the so-called local selfgovernment of communities, because the point it is not the welfare of the community $>\mathrm{a}<$ or the welfare of the community $>\mathrm{b}<$, but the point is the national welfare.

\section{VI) How can mankind be exhorted to rational use of the earth's resources and environmental protection}

\section{a) Respect for nature}

That nature should be treated with respect, is not a knowledge of the 21st century, but is very well established already in ancient philosophy. To believe that nature endures everything and recycles itself endlessly, is proved misconception. Those countries, that have allowed uncontrolled and unfiltered CO2 emissions, deal with the consequences. One of the unpleasant consequences is the formation of smog over metropolitan regions; this makes women and men not only breathe harder, but causes also serious diseases ${ }^{80}$. Religious texts - for example the Bible - as well as scholarly literature warns humanity at a reasonable use of resources of the earth and the environment.

\section{b) The Bible}

The Bible tells us something about how people should deal with nature: the following passage from Matthew chapter 6,2,25 (following) calls for respect for nature; the Evangelist Matthew ${ }^{81}$ offers this so very impressive reference ${ }^{82}$ :

"25 Therefore I tell you, do not worry about your life, what you will eat or drink; or about your body, what you will wear. Is not life more than

\footnotetext{
79 To new technology for the offshore-windparks Berlin Newspaper, N0. 206, $4^{\text {th }}$ of September 2015, p. 12.

${ }^{80} \mathrm{Cfr}$. for the city of Beijing

http://www.zeit.de/wissen/gesundheit/2014-02/smog-china-peking-gesundheit .

${ }^{81}$ Cfr. http://www.britannica.com/biography/Saint-Matthew-the-Evangelist .

82 Cited according the New International Version

https://www.biblegateway.com/passage/?search=Matthew+6\%3A25+-+34\&version=NIV .
} 
food, and the body more than clothes? ${ }^{26}$ Look at the birds of the air; they do not sow or reap or store away in barns, and yet your heavenly Father feeds them. Are you not much more valuable than they? ${ }^{27}$ Can any one of you by worrying add a single hour to your life $e^{[a]} ?^{28}$ "And why do you worry about clothes? See how the flowers of the field grow. They do not labor or spin. ${ }^{29}$ Yet I tell you that not even Solomon in all his splendor was dressed like one of these. ${ }^{30}$ If that is how God clothes the grass of the field, which is here today and tomorrow is thrown into the fire, will he not much more clothe you-you of little faith? ${ }^{31}$ So do not worry, saying, 'What shall we eat?' or 'What shall we drink?' or 'What shall we wear?' ${ }^{32}$ For the pagans run after all these things, and your heavenly Father knows that you need them. ${ }^{33}$ But seek first his kingdom and his righteousness, and all these things will be given to you as well. ${ }^{34}$ Therefore do not worry about tomorrow, for tomorrow will worry about itself. Each day has enough trouble of its own".

With all due respect it is a relatively unimportant issue whether this beautiful speech can be attributed to Jesus of Nazareth in person or to any other of his followers. More interesting are the big philosophical points in this speech; these are the following.

- This text calls for modesty rather than arrogance.

- This text calls for respect for nature and for the divine creation.

- This text asks to be content with the necessary and not to strive for untold wealth.

- This text is not an invitation for dull laziness. The text wants to have pointed out that sorrows and fears do not help, the decisive attitude is the reliance on God.

This text can be understood as a biblical invitation to today's road users in the 21st century, to act on the roads in consideration of the rules that shall guarantee safe conditions. Car-drivers shall not rush like Formula-OnePilots ${ }^{83}$ : Car-drives are e.g. not allowed to cut curves, this may jeopardize themselves and other road users. But Formula-One-Pilots do enjoy a high recognition among car-drives. There was the unfortunate accident of the former Formula-One World Champion Michael Schumacher, who caused a fatal crash when skiing. The sympathy of the fans is continuing unabated ${ }^{84}$. In my view this is caused not only by respect for the driving skills of Michael Schumacher as a Formula-One-Pilot, but it can be explained by the almost religious belief of the fans that Formula-One-Pilots have been especially selected and are immortal beings. The question, that Michael

\footnotetext{
${ }^{83}$ Cfr. https://www.formula1.com/ .

84 Cfr. http://www.focus.de/sport/formel1/ein-jahr-nach-dem-ski-unfall-das-drama-umformel-1-legende-michael-schumacher_id_4370014.html
} 
Schumacher might have caused the accident by too fast skiing and by disregarding rules, is hardly discussed and is not interesting.

\section{c) Henry Thoreau (1817 - 1862)}

On $4^{\text {th }}$ of July 1845 - it was the American Independence Day Henry Thoreau ${ }^{85}$ moved into a self-built log cabin in Concord at Walden Lake. Here he did live for about two years and two months independently, but not deposited. In his book $>$ Walden or Life in the Woods $<^{86}$ he described his simple life near the lake and in nature; but this is not a book about adventuring ${ }^{87}$ in nature, it deals such issues as society-structure and principles of economics. The following text is from the very beginning of the first chapter, named $>$ Econonmy $<{ }^{88}$ :

"When I wrote the following pages, or rather the bulk of them, I lived alone, in the woods, a mile from any neighbor, in a house which I had built myself, on the shore of Walden Pond, in Concord, Massachusetts, and earned my living by the labor of my hands only. I lived there two years and two months. At present I am a sojourner in civilized life again”.

In the following text there are shown the fears of the people that are living adapted to the occurrences of modern civilization and are beginning to move away from a nature-oriented life. $>$ Secundum naturam vivere ${ }^{89}$ is an ancient Greek philosophical attitude that can be traced in almost every important ancient school of philosophers ${ }^{90}$, for example to the Stoics ${ }^{91}$; the Roman philosopher Cicero ${ }^{92}$, who was an eclecticist ${ }^{93}$, transported this principle into ancient Roman philosophy. It is clear that living according to the principles of nature is not an end in itself, but leads mankind to questions that involve the structure of societies and the constitution of states. In the following text, that is again quoted from Thoreau $>$ Walden $<$, these implications are clearly seen:

\footnotetext{
${ }^{85}$ To him: Jack Turner: A Political Companion to Henry David Thoreau. Kentucky, 2009.

${ }^{86}$ Walden. A fully annotated edition. Edited by Jeffrey S. Cramer. Yale University Press, New Haven CT, 2004.

${ }^{87}$ The most prominent representative of the adventuring literature is Daniel Defoe (1660 $1731)$ in his $>$ Robinson Crusoe $<$ (1719).

${ }^{88}$ Cited after http://www.gutenberg.org/files/205/205-h/205-h.htm\#linkW1.

${ }^{89}$ In English it means >to live according to the principles of nature $<$.

${ }^{90}$ Cfr. Michael Erler, Roman Philosophy; in: Introduction to Latin Philology, edited by Fritz Graf, Stuttgart/Leipzig, 1997, pp. 537 sqq.

${ }^{91}$ Cfr. http://philosophie-der-stoa.de/philosophie-stoa-ethik.php.

${ }^{92}$ Cfr. De Finibus, 5,9: “Omne animal se ipsum diligit ac, simul et ortum est, id agit, se ut conservet, quod hic ei primus ad omnem vitam tuendam appetitus a natura datur, se ut conservet atque ita sit affectum”.

93 Woldemar Görler: Studies on Cicero's philosophy; Library of classical antiquity 50, Heidelberg, 1974.
} 
"The mass of men lead lives of quiet desperation. What is called resignation is confirmed desperation. From the desperate city you go into the desperate country, and have to console yourself with the bravery of minks and muskrats. A stereotyped but unconscious despair is concealed even under what are called the games and amusements of mankind. There is no play in them, for this comes after work. But it is a characteristic of wisdom not to do desperate things. When we consider what, to use the words of the catechism, is the chief end of man, and what are the true necessaries and means of life, it appears as if men had deliberately chosen the common mode of living because they preferred it to any other. Yet they honestly think there is no choice left. But alert and healthy natures remember that the sun rose clear. It is never too late to give up our prejudices. No way of thinking or doing, however ancient, can be trusted without proof. What everybody echoes or in silence passes by as true to-day may turn out to be falsehood tomorrow, mere smoke of opinion, which some had trusted for a cloud that would sprinkle fertilizing rain on their fields. What old people say you cannot do, you try and find that you can. Old deeds for old people, and new deeds for new. Old people did not know enough once, perchance, to fetch fresh fuel to keep the fire a-going; new people put a little dry wood under a pot, and are whirled round the globe with the speed of birds, in a way to kill old people, as the phrase is. (...)".

Here are the big philosophical points of this text:

- This text is famous for its pleading for civilian disobedience ${ }^{94}$; in the $20^{\text {th }}$ century these organizations, that tried to protect environment, did rely on this principle.

- The experiences of former generations are worthful, but this does not mean that there should be no changes.

- Trial and error ${ }^{95}$ is the method that helps to find the best way; the aim is true knowledge, not superficial knowledge.

- The power of nature shall be used by mankind, but nature shall not be destroyed.

\section{c) On environmental protection and community organizations}

Earlier environmental organizations have been ridiculed in the industrialized countries ${ }^{96}$ and were said to be enemies of progress. But this incorrect assessment is overcome. It should not be forgotten that these organizations would not have existed, if not courageous men and women

\footnotetext{
${ }^{94}$ Howard Zinn, "Introduction" for The Higher Law: Thoreau on Civil Disobedience and Reform, Wendell Glick, ed., Princeton, 2004.

${ }^{95}$ Reinhold Zippelius, Trial and error in Jurisprudence, Academy of Science, Mainz, 1991.

${ }^{96}$ An illustrative example is the German Green Party, whose member Joschka Fischer did become the German Minister of Foreign Affairs (1998 - 2005).
} 
grouped in citizens' initiatives. This is a good example for the fact that in the representative democracy the elements of direct citizen participation ${ }^{97}$ are very important. It is to be noticed that the law of the European Union does privilege environmental protection organizations ${ }^{98}$ insofar as these do want to take legal action against the planning approval process of infrastructure projects.

\section{Relevance of education for better infrastructure and environmental protection}

Women and men need not be scientists in the field of education to recognize the following insights:

- Without education the perception of basic democratic rights is very difficult. The one, who is not educated, is rare at an up-to-date level of political and social developments; the formation of an own and independent opinion is very difficult.

- Countries, that permit illiteracy ${ }^{99}$, are dictatorships; a dictator has a quasi-natural fear of his people and wants to keep it in stupidity.

- The one, who is educated, is not necessarily a friend of nature, but the statistical probability tells us that an educated person generally pays more respect to nature as the uneducated.

- What highly qualified staff does a modern state need? First of all there it the group of engineers, among which the doctors are of great importance. Furthermore there are the lawyers, but not this kind of lawyers, which are technocrats of the ruling power, but only these, who are committed to the principles of morality ${ }^{100}$. To these principles do belong the human rights ${ }^{101}$ and the essential principles of democracy model, such as a consistent separation of powers. Of course, a modern society does need the representatives of modern social sciences, to which are belonging sociology, political science, linguistics and other disciplines.

For the topics of this key-note speech the consequences are clear:

- Where there are no (good) engineers for construction of roads, there will be no good transport infrastructure. If there is no good transport infrastructure, good managers for economic matters do have a difficult job.

\footnotetext{
97 Cfr. http://www.nzz.ch/meinung/debatte/wie-vertragen-sichdirekte-demokratie-undwirtschaft-1.18265687?extcid=Newsletter_19032014_Top-News_am_Morgen

${ }^{98} \mathrm{Cfr}$. http://curia.europa.eu/juris/liste.jsf?language=de\&num=C-115/09.

${ }^{99}$ In Egypt the author did meet people that could neither read nor write.

${ }^{100}$ Hans Kelsen $(1881$ - 1971) is one of the best legal philosophers this world has ever seen, but his theory of eliminating moral influences from legislation is to be discussed.

${ }^{101}$ One of the most important results of the American Revolution (1776) and the French Revolution (1789) is the warranting of human rights.
} 
- Where there are no (good) lawyers, the enforcement of law is only an empty formula; in this case nature is not protected, when new transport infrastructure is erected. Without enforcement of rules of the relevant Road Traffic Law will be disregarded, the consequences are violence on the roads and death on the roads.

\section{Results}

Here are the results of this paper:

- In order to prevent misunderstandings I want to put the following clear: With the aim of greatest possible environmental protection it is compatible that the infrastructure is improved. For industrial nations as e.g. Germany the maintenance of existing transport infrastructure should take precedence over an expansion of the existing transport infrastructure. On the one hand, this saves financial resources, on the other hand, it would be a fatal mistake to regard the existing transport infrastructure as a matter of selfevidence. Furthermore, it is clear that the countries of Africa do need and deserve a better transport infrastructure; UN and the European Union are obliged to help.

- Without intending to limit individual mobility, the conservation of nature is a very demanding challenge, that faces modern states and their lawmakers. Difficult is the question which aspect is more important for a juridical assessment: To state that the journey by car to point $>\mathrm{a}<$ is less important than the journey by car to point $>\mathrm{b}<$ cannot be managed ${ }^{102}$. Nevertheless, only a very few individual cases are clear: The ambulance car has to have the right of way; the police car has to have the right of way et al.

- If a good transport infrastructure is build up, traffic conditions have to be limited by speed limits: Freeways are necessary to cope with the traffic conditions of the 21th century, but they are not designed for the wishful thinking of private speeders that feel like Formula-One-Pilots; freeways are necessary for reasonable usage, e.g. for the quick transport of goods. A tempo limit for dangerous road sections such as bridges and sharp turns in the course of freeways is self-evident. But what about the downtown traffic? The cores of out towns deserve particular protection: The noise protection for the affected neighborhood - e.g. kindergartens and nursing homes - is an objective that is apparent to reasonable citizens. The establishment of pedestrian areas is absolutely necessary, people should understand, that not for every action car-driving is necessary. These simple examples serves two purposes: On the one hand, they do serve the aim of road safety, on the other

\footnotetext{
${ }^{102}$ Here the reference to the philosophical model of the ancient philosopher Plato is to be done; Plato did assign the people within a hierarchical order a certain place; it is clear that this philosophy is not good guideline for a modern democracy
} 
hand, they do serve the protection of the environment: To repeat it once again: Slower driving reduces CO2 emissions. To go by foot and to go by bicycle are easy methods that help mankind to go back to roots.

- From a technical perspective nuclear energy is an ingenious invention. Under normal circumstances it has no real negative effects on the environment. But it has to be seen that the disasters of Chernobyl and Fukushima have unfortunately demonstrated that the nuclear energy can be uncontrollable: This shows the hybris of mankind: How can mankind rely on an energy that in the end cannot be controlled.

The following is clear: The final game has already begun; a good result is still possible; but the reasonable people do not want to have a decision in a penalty shootout.

\section{References:}

Konrad Bauer/Franz-Rudolf Herber (ed.): Law and technology, Vol. II, Bonn, 2011.

Richard T. Corlett \& Richard B. Primack: Tropical Rainforest Conservation: A Global Perspective, in: Walter Carson and Stefan Schnitzer (ed.): Tropical Forest Community Ecology. 2008, Chapter 26.

Woldemar Görler: Studies on Cicero's philosophy; Library of classical antiquity 50, Heidelberg, 1974.

Franz-Rudolf Herber, EU-Twinning Project for Road Safety in Egypt, in: Bavarian Administrative Law Journal 2012, p. 298 - 300.

Franz-Rudolf Herber, Egyptian Road Act Proposal, in: Without editor: The EU twinning expertise for Enhancing Road Safety on Egypt, 2nd edition, Cairo, 2012 disc, under Annex, No. 53, p. 1 - 86.

Franz-Rudolf Herber, German Road Law in its constitutional anchoring, in: Konrad Bauer/Franz-Rudolf Herber (ed.), Law and technology, Vol. II, Bonn, 2011, p. 15 - 47.

Franz-Rudolf Herber, Network Planning - Network Streamlining - Network Formation, in: Durner (ed.), Reports the Federal Highway Research Institute, Bergisch-Gladbach, 2012.

Franz-Rudolf Herber: Zur Endlagerung radioaktiver Abfälle und zum Standortauswahlgesetz, in: BayVBl. 2014, 353 - 362.

Franz-Rudolf Herber/Diana Boteva, Bulgarian Road Law in its constitutional anchoring, in: Konrad Bauer/Franz-Rudolf Herber (ed.), Law and technology Vol. II, Bonn, 2011, p. 341-355.

Franz-Rudolf Herber/Sebastian Heidorn: Speed limit on motorways, in: Bavarian Administrative Law Journal 2009, 129 - 137.

Parag Khanna: How is the world ruled, Berlin, 2012.

Kurt Kodal: Handbook on road law in the Federal Republic of Germany. 7th edition. Munich, 2010. 
Maria D. Lane: Geographies of Mars. Seeing and Knowing the Red Planet, Chicago, 2010.

Paul Arthur Schilpp (ed.): Albert Einstein: Philosopher-Scientist. Library of Living Philosophers, Cambridge University Press, Volume VII, London, 1949.

Piotr Swiatecki: Polish Road Law in its constitutional anchoring, in: Konrad Bauer/Franz-Rudolf Herber (ed.), Law and technology II, Bonn, 2011, p. 71 $-98$

Jack Turner: A Political Companion to Henry David Thoreau. Kentucky, 2009.

Howard Zinn, "Introduction" for The Higher Law: Thoreau on Civil Disobedience and Reform, Wendell Glick, ed., Princeton, 2004.

Reinhold Zippelius, Trial and error in Jurisprudence, Academy of Science, Mainz, 1991. 